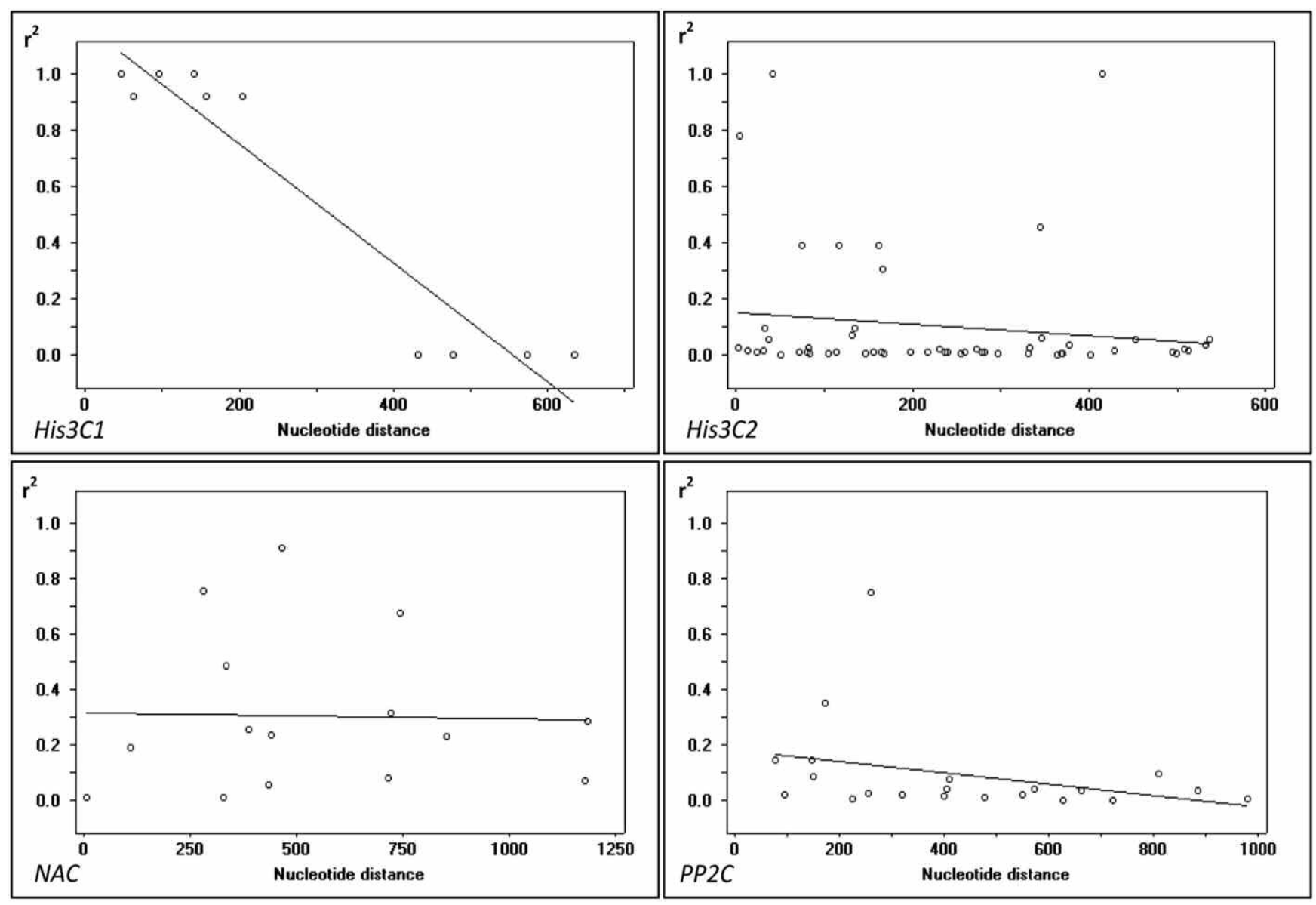

Figure S1. - Continued.

\title{
How small and constrained is the genome size of angiosperm woody species
}

\author{
By D. OHRI $\left.{ }^{*}\right)$ \\ (Received $8^{\text {th }}$ May 2015)
}

\begin{abstract}
Angiosperm hardwood species are generally considered to show an average smaller genome
*) Corresponding author: DEEPAK OHRI. Amity University Uttar Pradesh (Lucknow Campus), Malhaur (Near Railway Station), Gomti Nagar Extension, Lucknow- 226028 (U.P.), India. Telephone: +91-9452734145.
E-Mail: ohri_deepak@rediffmail.com; dohri@lko.amity.edu

size with a narrow range of variation than their herbaceous counterparts. Various explanations pertaining to limitations of cell size exerted by wood fibers, the requirement of smaller stomata, longer generation time, large population size, etc., have been put forward to account for their small and constrained genome size. Yet studies done in the past several years show that genomically as well as evolutionarily, hardwoods are as diverse and active as their herba- 
ceous counterparts. This is entirely supported by the presence of well developed inter and intraspecific polyploid series and natural triploidy in many genera. Polyploidy, in some instances has been shown to confer adaptability to arid and salt stress conditions and in colonization of new areas. Moreover, hardwoods also show reasonable amenability to the induced polyploidy which abruptly changes the balance between nuclear and cell size. Polyploidy has been induced in many hardwoods to restore fertility in interspecific hybrids and for the production of triploids.

Furthermore, some cases studied show that genome size variation in hardwoods can be as variable as that of herbaceous species. Genome size has been shown to vary remarkably both at homoploid level as well as by polyploidy in certain genera. In the same way, the genome size is not correlated with the habit in certain groups having both herbaceous and woody taxa. This point is further proved by the presence of secondary and insular woody habit in certain cases where either the transition to woodiness is not followed by any diminution in the genome size, or the genome size of insular woody species may be even more than that of the congeneric herbaceous species. This shows that woody habit does not by itself put any constraints on the genome size either at homoploid or at polyploidy levels. The genome size in fact, not only varies significantly in many congeneric woody species but also may not show any correlation with the habit when woody and herbaceous species are compared in some narrow taxonomic groups studied.

Key words: hardwoods, constrained and small genome size, genome size variation, natural and induced polyploidy, insular and secondary woody habit.

\section{Introduction}

Genome size in angiosperms varies 2300-fold from $1 \mathrm{C}$ value of just $0.063 \mathrm{pg}$ in Genlisea margaretae (Lentibulariaceae) (GREILHUBER et al., 2006) to 152.23 pg in Paris japonica (Melanthiaceae) (PELLiCER et al., 2010). The mechanisms underlying this large variation are now fairly known but its non-random distribution in organisms of varying complexity is still a big puzzle which is known as C-value enigma (GREGORY, 2001). Although it is known that most of the DNA in a eukaryote genome is comprised of repetitive DNA, there are no empirical data which identify the forces responsible for causing variation of this component of DNA. Nevertheless, the availability of genome size data for about 4500 angiosperm species (BENNETT and LEITCH, 2010), allows us to seek various explanations in terms of phenotype, function, or ecological adaptations for this wide range of variation. Earlier work provided a functional view to this non-informative DNA because of strong positive correlation of genome size with nuclear and cell size, cell cycle time and minimum generation time of herbaceous plants leading to the concept of nucleotype (BENNETT, 1971, 1972, 1987). Later studies have further reinforced the straight positive relationship of genome size with cell size (KNIGHT and BeAulieu, 2008; Beaulieu et al., 2008; LomaX et al., 2009), cell cycle duration regardless of ploidy level (FrANCIS et al., 2008) particularly the S-phase (Simova and Herben, 2011). Genome size has been seen to have negative effect on root meristem growth rate in 8 herbaceous species as those with larger genome size show slower root growth velocity (GRUNER, 2010 ). The direct positive relation of genome size with cell cycle time manifests itself in various growth and life history conditions. A comparison of 156 species of weeds and 2685 other species shows that both mean 4C DNA amount $(11.74 \mathrm{pg})$ and genome size $(3.79 \mathrm{pg})$ of weeds was significantly smaller than mean 4C (28.13 pg) and genome size (12.14 pg) of other species (BENNETT et al., 1998). Similarly, invasiveness has been observed to be negatively associated with genome size in Pinus species belonging to subg. Pinus (GrotkopP et al., 2004), Artemesia species (GARCIA et al., 2008), and various genotypes of Phalaris arundinacea (LAVERGNE et al., 2010). Likewise, species naturalized in Czech Republic have been shown to possess smaller genome size than their congeners which are otherwise not naturalized or invasive in other parts of the world (KUBESOVA, 2010). Moreover, a broad comparison of 3676 angiosperm species has shown a significantly negative effect of $1 \mathrm{C}$ and basic genome size on invasiveness among herbs, dicots, monocots, perennials, non-perennials, diploids, polyploids, Compositae and Poaceae and non-significant correlation among trees and Fabaceae (CHEN et al., 2010). Furthermore, a differential sensitivity of cell division and cell expansion, to low temperatures, operates through differences in DNA amounts. It has been demonstrated in grassland community in North England that the early spring sprout- 
ing plants are those which undergo mitotic divisions in preceding warmer conditions followed with rapid growth by water uptake in spring (GRIME et al., 1985). OHRI and PISTRICK (2001) however, failed to observe a tight correlation between genome size and early spring growth in 75 Allium species studies. In a broad comparison based on 3874 angiosperm species OHRI (2005) found that both mean $4 \mathrm{C}(5.63 \mathrm{pg})$ and $1 \mathrm{Cx}$ DNA $(1 \mathrm{Cx}=2 \mathrm{C} /$ ploidy level $)$ values $(1.21$ pg) of woody angiosperms were significantly lower than those of herbaceous angiosperms (28.85 and $5.63 \mathrm{pg}$ respectively). This was also true of all the subsamples including temperate and tropical angiosperms and dicots, tropical monocots and the family Fabaceae, when 4C and $1 \mathrm{Cx}$ values of woody and herbaceous species included in these samples are compared. Therefore, the woody species consistently showed smaller holoploid and $1 \mathrm{Cx}$ values with a narrow variance than their herbaceous counterparts (OHRI, 2005). Woody monocots which do not produce true wood, however, have $4 \mathrm{C}$ and $1 \mathrm{Cx}$ values 3.75 and 4.0 -fold respectively, greater than those of woody dicots (OHRI, 2005). The present discussion would therefore be restricted to woody dicots only. The $4 \mathrm{C}$ DNA amounts in tropical woody dicots differ 47.8-fold ranging from $0.74 \mathrm{pg}$ in Dissotis canescens $(2 \mathrm{n}=\mathrm{c} .28-32)$ to $35.4 \mathrm{pg}$ in Kadsura longespicata $(2 \mathrm{n}=28)$ and is restricted to $50.5 \%$ of the range known for tropical herbaceous dicots. The $1 \mathrm{Cx}$ values of tropical woody dicots, however, show 55.6 -fold variation from $0.08 \mathrm{pg}$ in octoploid Coriaria myrtifolia $(2 \mathrm{n}=\mathrm{c} .72)$ to $4.45 \mathrm{pg}$ in diploid Bougainvillea spectabilis $(2 \mathrm{n}=34)$. It is important to note that both temperate and tropical woody dicots had significantly lower mean 4C (4.45 pg and $4.49 \mathrm{pg}$ respectively) and $1 \mathrm{Cx}$ values (0.89 $\mathrm{pg}$ and $0.94 \mathrm{pg}$ respectively) than their herbaceous counterparts (OHRI, 2005) which falls in the range of very small $<1.4 \mathrm{pg}$ according to LEITCH et al. (1998). Moreover, the range of variation shown by woody species is also much narrow than that shown by the herbaceous species (OHRI, 2005). Similar results were obtained by BEAULIEU et al. (2010) who found a strong influence of growth form on genome size, with woody lineages being slow in accumulating changes in genome size as related to herbaceous species. This pattern was consistent in both Monocotyledons and Fabaceae irrespective of $1 \mathrm{C}$ or $1 \mathrm{Cx}$ DNA content (BEAULIEU et $a l ., 2010)$. This is despite the presence of widespread palaeoploidy and high basic numbers in woody species (MeHra, 1976; MoraweTz, 1986; EHRENDORFER, 1987). However, gymnosperms despite their long generation time possess large genomes (OHRI and KHOSHOO, 1986; MURRAY, 1998).

The question here arises is, which common constraints influence the genome sizes of this polyphyletic assemblage of woody species, belonging to all eudicot orders except Geraniales and Gunnerales (Groover, 2005). Nevertheless, tree habit though being polyphyletic has some common features such as size, longevity, reproductive output (prodigious seed production), predominantly outcrossing behavior, high levels of intra and interspecific gene flow, very large effective population sizes, slower mutation rates per unit time, nucleotide substitution and speciation (PETIT and HeMPe, 2006).

Some explanations have been provided to account for the retention and perpetuation of small genome size of woody dicot species. These pertain to both structural constraints related to growth form and life history traits. The robust relationship between cell size and genome size would mean that small cambial cells which form wood fibers put constraints on nuclear and chromosome size (StebBins, 1950; KHoshoo, 1962). Another such constraint has been shown in case of guard cell length and stomatal density by BEAULIEU et al. (2008). This constraint manifests in small and dense stomata of angiosperm trees which confer greater stomatal conductance and transpiration rate required to move water and nutrients through longer xylem pathways (WOODWARD, 1998). At the same time, in dry environment, smaller stomata respond quickly to water stress (due to their greater membrane surface area to volume ratio) while high stomatal density maximizes $\mathrm{CO}_{2}$ diffusion during optimal photosynthetic conditions (AASAMAa et al., 2001; Hetherington and WOODWARD, 2003). Furthermore, longer generation time and large population sizes (PETIT and HAMPE, 2006) of woody species allow for fewer opportunities for the accumulation of genomic changes and the removal of deleterious mutations and excess DNA, therefore maintaining small genome size (BEAULIEU et al., 2010). Gymnosperms also have longer generation time however; it is worth mentioning here that they have lower photosynthetic rates and on average marginally less dense wood than the angiosperms (KNIGHT and BEAULIEU, 2008). 
Nevertheless, the data accumulated over the past years on the chromosome and genome size evolution of woody dicots shows that their genome size though small, is not as constrained as it has been commonly considered. The genome size does not show very tight relationship with structural and life history traits as mentioned above, on the contrary it can show dramatic increases by polyploidy (both induced and natural) and by retrotransposons. Some of the mechanisms responsible for producing the sharp variation in genome size of woody species are discussed here.

\section{Inter and Intraspecific polyploidy}

A large number of hardwood families and genera possess the same haploid number and have evolved at diploid level (MEHRA, 1972; MEHRA et al., 1972; KREMER et al., 2007; OHRI and KHoshoo, 1987; OHRI and AHUJA, 1990, 1991; D'EMERICO et al., 1995; Zoldos et al., 1999; KUMAR and RAO, 2002; WANG et al., 2005; OUdJEHIH and Bentouati, 2006; CHOKCHAICHAMNANKIT et al., 2008; RIBEIRO et al., 2011; HYNNIEWTA et al., 2011; CoulleRI et al., 2012). However, a large heterogeneity of somatic chromosome numbers is exemplified by Meliaceae with $2 \mathrm{n}=16,20,22,24,26,28$, $30,32,36,38,40,42,44,46,48,50,52,54,56$, $58,72,78,80,84,92,100, \mathrm{c} 150, \mathrm{c} 280, \mathrm{c} 360$ (Style and Vosa, 1971; Khosla and Styles, 1975). Furthermore, besides the presence of palaeoploidy and high basic numbers certain families and genera are characterized by the evolution of well developed polyploid series. Notable among these are Alangium (2x,3x), Randia $(2 \mathrm{x}, 4 \mathrm{x})$, Rauwolfia $(4 \mathrm{x}, 6 \mathrm{x})$ Callicarpa $(2 \mathrm{x}, 8 \mathrm{x}, 10 \mathrm{x}), \quad$ Litsea $(2 \mathrm{x}, 4 \mathrm{x}), \quad$ Trema $(2 \mathrm{x}, 8 \mathrm{x})$ (MEHRA and BAwA, 1969), Antidesma $(2 \mathrm{x}, 6 \mathrm{x}, 8 \mathrm{x}, 9 \mathrm{x}) \quad$ (HANs, 1970), Terminalia (2x,4x,6x) (GILl et al., 1982; OHRI, 1996), Fraxinus 2x,4x,6x) (Nesom, 2010), Rhododendron $(2 \mathrm{x}, 6 \mathrm{x}) \quad(\mathrm{DE}$ et al., 2010), Tetrameranthus $(2 \mathrm{x}, 4 \mathrm{x}), \quad$ Rollinia $(2 \mathrm{x}, 4 \mathrm{x}, 6 \mathrm{x}, 8 \mathrm{x}) \quad$ (Morawetz, 1986), Magnolia (2x,4x,6x) (BISWAS and SHARMA, 1984; PARRIS et al., 2010), Annona (2x,4x), Cochlospermum $(2 \mathrm{x}, 3 \mathrm{x}, 4 \mathrm{x}, 6 \mathrm{x}), \quad$ Barringtonia $(2 \mathrm{x}, 4 \mathrm{x})$ (MORAWETz, 1986), and Betula $(2 \mathrm{x}, 4 \mathrm{x}, 6 \mathrm{x}, 10 \mathrm{x})$ (FuRLOW, 1990), Leucaena $(2 \mathrm{x}, 4 \mathrm{x})$ (PAlOMino et al., 1995), Trigonobalanus (2x,6x) (CHEn et al., 2007), Desoxylum (2x,8x) (KHOSLA and StYles, 1975), Aglaia (2x,4x) (Mehra et al., 1972), Urvillea (2x,4x,8x) (FERRUCCI, 2000, URDAMPILLETA et al., 2006).
Some of the examples of intraspecific polyploid series are Swietenia mahagoni $(2 \mathrm{x}, 3 \mathrm{x}, 4 \mathrm{x}, 6 \mathrm{x}, 8 \mathrm{x}, 9 \mathrm{x}, 10 \mathrm{x}), \quad$ Aphanomixis polystachya $(2 \mathrm{x}, 4 \mathrm{x}, 8 \mathrm{x})$ (KHOSLA and STYLES, 1975), Annona squamosa, Jatropha curcas, Leea indica, Ricinus communis, Salix tetrasperma, Trema orientalis, Wrightia tinctoria, Xeromphis dumetorum, Zizyphus oenoplia, Terminalia bellirica $(2 \mathrm{x}, 4 \mathrm{x})$, Grewia hainesiana, Lawsonia alba $(3 \mathrm{x}, 4 \mathrm{x})$, Emblica officinalis $(4 \mathrm{x}, 8 \mathrm{x})$, Terminalia chebula, Toona ciliata $(2 \mathrm{x}, 4 \mathrm{x}, 6 \mathrm{x})$, Lantana camara $(2 \mathrm{x}, 3 \mathrm{x}, 4 \mathrm{x}, 6 \mathrm{x}), \quad$ Syzygium cumini $(2 \mathrm{x}, 3 \mathrm{x}, 4 \mathrm{x}, 5 \mathrm{x}, 6 \mathrm{x})$, Zizyphus mauritania $(2 \mathrm{x}, 4 \mathrm{x}, 5 \mathrm{x}$, 6x,8x) (GILl et al., 1990; MATHUR et al., 1995), Hydnocarpus laurifolia (2x,4x), Malpighia glabra $(2 \mathrm{x}, 4 \mathrm{x})$, Geijera parviflora $(12 \mathrm{x}, 16 \mathrm{x}, 18 \mathrm{x})$, Eugenia jambolana (2x,3x,4x, 5x,6x), Eugenia uniflora $(2 \mathrm{x}, 3 \mathrm{x})$, Duabanga sonneratioides $(3 \mathrm{x}, 4 \mathrm{x})$ (SINGHAL et al., 1985), Ixora rosea $(2 \mathrm{x}, 3 \mathrm{x})$, Xeromphis spinosa $(2 \mathrm{x}, 4 \mathrm{x})$ (BEDI et al., 1981), Ulmus americana $(2 \mathrm{x}, 4 \mathrm{x})$ (WHITTEMORE and Olsen, 2011) Betula schmidtii and B. utilis $(2 \mathrm{x}, 4 \mathrm{x}), B$. chinensis $(6 \mathrm{x}, 8 \mathrm{x}), B$. glandulosa $(2 \mathrm{x}, 3 \mathrm{x})$, B. devurica $(4 \mathrm{x}, 6 \mathrm{x}, 8 \mathrm{x})$ (Furlow, 1990), Leucaena esculenta subsp. esculanta $(2 \mathrm{x}, 4 \mathrm{x})$ (PAlomino et al., 1995), Zizyphus jujube $(4 \mathrm{x}, 5 \mathrm{x}, 8 \mathrm{x}), Z$. rotundifolia $(4 \mathrm{x}, 6 \mathrm{x})$ (KHOSHOO and SinGH, 1963), Antidesma acuminatum $(2 \mathrm{x}, 6 \mathrm{x})$ (Hans, 1970), Cipadessa baccifera (2x,4x) (KHOSLA and STYLES, 1975), Turnera ulmifolia complex $(2 \mathrm{x}, 4 \mathrm{x}, 6 \mathrm{x}, 8 \mathrm{x})$ (LOPEZ et al., 2011), Acacia tortilis $(2 \mathrm{x}, 3 \mathrm{x}, 4 \mathrm{x}, 8 \mathrm{x})$ (OBALla and Olngotie, 1993; BukHari, $1997 \mathrm{a}, \mathrm{b}$; EL FerChichi et al., 2009), Acacia dealbata (2x,3x,4x) (BLAKESLEY et al., 2002), Eugenia hyemalis, E. punicifolia $(2 \mathrm{x}, 4 \mathrm{x})$, E. uniflora $(2 \mathrm{x}, 3 \mathrm{x})$ (CosTA and ForNIsMartins, 2006a), Psidium cattleianum (4x,3x, $7 \mathrm{x}, 8 \mathrm{x}$ ) (Costa and Fornis-Martins, 2006b), Acacia senegal (2x,3x,4x,6x) (ODEE et al., 2015), Callicarpa macrophylla (2x,4x) (CONTRERAS, 2011), Urvillea ulmacea $(2 \mathrm{x}, 8 \mathrm{x})$ (URDAMPILLETA et al., 2006), Psidium cattleianum (4x,6x,7x,8x) (Costa and Forni-Martins, 2006b), Olea europaea complex $(2 \mathrm{x}, 4 \mathrm{x}, 6 \mathrm{x})$ (BESNARD et al., 2008).

Some studies on woody species have shown that polyploids exhibit larger stomata in low density, a lower osmotic potential at full turgor, and a thick epidermis, all of which tend to reduce water loss or maintain turgor in the case of lower water potential. This is depicted by the studies on different cytotypes. In Atriplex canescens of the three cytotypes $2 \mathrm{x}, 4 \mathrm{x}, 6 \mathrm{x}$, those of higher ploidy levels show greater 
resistance to embolism through a trade off between water conducting efficiency (decreased due to large vessel diameter) and safety against hydraulic failure therefore possessing better adaptation to grow in areas of water stress as compared with $2 \mathrm{x}$ cytotype which is more mesic (HAO et al., 2013). The tetraploid $(2 \mathrm{n}=36$, $2 \mathrm{C}=5.11 \mathrm{pg}$ ) populations of Atriplex halimus also show greater adaptability to arid conditions of North Africa and eastern Mediterranean as compared to the diploid $(2 \mathrm{n}=18$, $2 \mathrm{C}=2.40 \mathrm{pg}$ ) populations which occur in western Mediterranean (WALKER et al., 2005). Adaptability to more arid conditions is also shown by the tetraploid $(2 \mathrm{n}=4 \mathrm{x}=52$, $2 \mathrm{C}=2.95-3.03 \mathrm{pg}$ ) as compared with the diploid populations $(2 \mathrm{n}=2 \mathrm{x}=26,2 \mathrm{C}=1.39-1.40 \mathrm{pg})$ of Acacia tortilis ssp. raddiana (EL FERCHICHI OUARDA et al., 2009). Similarly Larrea tridentata, a North American desert shrub shows habitat differentiation with respect to its $2 \mathrm{x}, 4 \mathrm{x}, 6 \mathrm{x}$ cytotypes where higher ploidy levels show distribution in more arid regions. This ability of $4 \mathrm{x}$ and $6 \mathrm{x}$ cytotypes to grow well in regions of water stress could be due to decrease in stomatal density by increasing the cell size resulting in reduced water loss (HUNTER et al., 2001). Such a difference of geographic distribution has also been found in $2 \mathrm{x}$ and $4 \mathrm{x}$ cytotypes of Ulmus americana where $4 \mathrm{x}$ shows a much wider and northern distribution than 2x (WHITTEMORE and OlSEN, 2011). Similar observations have been made in Coffea canephora and $C$. arabica which show decrease in stomatal and epidermal cell frequency and increase in guard cell length with increase in ploidy level (Mishra, 1997). A study on 2x and 4x cytotypes of Robinia pseudoacacia showed that $4 \mathrm{x}$ has better salt tolerance capacity than $2 \mathrm{x}$ after treatment. This is manifested by decrease in photosynthesis and defense related enzyme activities and increase in reactive oxygen species, malondialdehyde content and relative increase in electrolyte leakage in $2 \mathrm{x}$ after salt treatment (WANG et al., 2013).

\section{Induced polyploidy}

Polyploidy has been successfully induced in a number of woody species for producing triploids, increase in fiber length, enhancing fruit and ornamental traits, and restoring fertility in interspecific hybrids. Commonly observed effects manifested by induced tetraploidy are compact restricted growth (reduction in intern- odal distance), thicker leaves (low leaf index ratio), increase in leaf area, increase in guard cell length and number of chloroplasts per guard cell and decrease in number of stomata per unit area as observed in Morus alba (DWIVEDI et al., 1989), Buddleia globosa (Rose et al., 2000), Rhododendron hybrids (VAINOLA, 2000), Pyrus pyrifolia (KADOTA and NiIMI, 2002), Punica granatum (SHAO et al., 2003), Zizyphus jujube (Gu et al., 2005), Platanus acerifolius (LIU et al., 2007), Lespedeza formosa (WEI et al., 2007), Populus (WANG et al., 2013), Acacia mangium (HARBARD et al., 2012), Betula platyphylla (MU et al., 2012), Acacia mearnsii (BECK et al., 2003), Paulownia tomentosa (TANG et al., 2010), Bougainvillea (ZADOO et al., 1975), Morus (VERMA et al., 1986), Betula spp. (SARKILAHTI and VAlanNe, 1990), Lagerstroemia indica (ZHANG et al., 2010), Eucalyptus globulus (LiN et al., 2010), Betula platyphylla (MU, 2012), Acacia crassicarpa (LAM et al., 2014).

A detailed anatomical study of diploid and induced tetraploid types of Manihot esculenta has shown a clear difference with respect to secondary vascular tissues which are more developed in $2 x$ than in $4 x$ types. In the secondary xylem of $4 \mathrm{x}$ plants the radial parenchyma cells are wider with thinner walls and little starch and more vessel groupings with little tylose inside elements leading to retention of larger quantity of water contrary to $2 \mathrm{x}$ plants with narrower parenchyma cells with much starch, thicker walls, and more solitary vessel elements with tylose inside (NASSAR et al., 2008).

\section{Occurrence of natural triploids}

Natural triploids have been found among populations of otherwise diploid species. They generally originate by the production of unreduced gametes (OHRI and ZADOO, 1986; BUTORINA, 1993). Rare triploid individuals have been observed in different species of Quercus, and identified by various methods. They generally show increase in stomatal and overall size as compared to the diploids (NAUJKos et al., 1995; DZIALUK et al., 2007; LEFORT et al., 1998, 2000; Burda and SHCHEPotiev, 1973; Butorina, 1993). Similar observations have been made in triploid Populus tremuloides (EINSPAHR et al., 1963; BENSEN and Einspahr, 1967). These triploids are known to have comparatively larger wood cells, a positive character for paper industry. A high rate $(69 \%)$ of triploidy has been recorded 
in Populus tremuloides in western USA. However, the highest frequency of triploidy occurs in unglaciated drought prone regions of North America where largest clone sizes have been recorded (Mock et al., 2012).

\section{Genome size variation at homoploid level and by polyploidy}

The hardwoods generally possess a small genome size with a narrow range of variation (OHRI and KuMAR, 1986; OHRI et al., 1986; OHRI and KHoshoo, 1987; OHRI et al., 2004; OHRI, 1996, 2002, 2005). However, two issues need to be considered here: the presence of remarkable interspecific genome size variation in some hardwood genera and the extent of genome size variation in woody and herbaceous elements within some narrow taxonomic groups.

Studies done in past several years have shown interesting patterns of variation at both holoploid and 1Cx levels in many hardwood genera. The 2C DNA contents of 12 Eucalyptus species studied conform to their sectional classification. They range from $0.77 \mathrm{pg}$ in E. citriodora to 1.47 pg in $E$. saligna therefore showing a 1.9 -fold difference. The species of subgenus Symphomyrtus show 2C DNA values from $1.09 \mathrm{pg}$ ( $E$. globulus) to $1.47 \mathrm{pg}$ (E. saligna), while those of subgenus Corymbia have much smaller 2C DNA values varying from $0.77 \mathrm{pg}$ in $E$. citriodora to $0.80 \mathrm{pg}$ in E. torelliana (GRATTAPAGALIA and BRADSHAW, 1994). The fleshy fruited species of Myrtaceae however, possess smaller genome size than capsular species of Eucalyptae and Melaleuceae. Twenty eight diploid $(2 \mathrm{n}=2 \mathrm{x}=22)$ species show a variation in $2 \mathrm{C}$ values from $0.486 \mathrm{pg}$ in Gomidesia schaueriana to 0.636 pg in Eugenia multicostata while two tetraploids Psidium acutangulum and P. cattleianum show $1.053 \mathrm{pg}$ and $1.167 \mathrm{pg}$ respectively (CosTA et al., 2008).

CROs et al. (1995) observed a 2-fold variation in 12 diploid $(2 \mathrm{n}=22)$ Coffea species belonging to subgenus Coffea with $2 \mathrm{C}$ values ranging from $0.95 \mathrm{pg}$ in C. racemosa to $1.78 \mathrm{pg}$ in C. humilis. C. arabica which is an allotetraploid $(2 \mathrm{n}=44)$ has $2 \mathrm{C}$ value of $2.61 \mathrm{pg}$. A more detailed study on 15 species showed a 1.6 -fold difference in $2 \mathrm{C}$ values from $1.03 \mathrm{pg}$ in Coffea racemosa to 1.76 pg in C. humilis (NoIROT et al., 2003). An ecological trend relating small genome size with water deficit and large genome size with more humid conditions has been shown in both the studies. Similarly, a 1.47-fold variation ranging from C. humboldtiana and C. mauritiana $(0.96$ $\mathrm{pg})$ to $C$. millottii (1.41 pg) has been shown in 44 Coffea species $(2 \mathrm{n}=2 \mathrm{x}=22)$ (Mascarocoffea) from Indian Ocean islands (RAZAFINARIVO et al., 2012). Here again small genome size is associated with drier habitats. Moreover, a significant correlation was found between leaf length and 2C DNA content and a weak but significant correlation between guard cell length (GCL) and 2C DNA content (RAZAFINARIVo et al., 2012). Ten diploid $(2 \mathrm{n}=20)$ species of Dalbergia show a 1.3fold variation in 4C DNA contents from $5.85 \mathrm{pg}$ $D$. lanceolaria to $7.88 \mathrm{pg}$ in $D$. horrida. While the tree species show a range from $5.85 \mathrm{pg}$ in $D$. lanceolaria to $7.22 \mathrm{pg}$ in $D$. sissoides the shrubby and climber species included in the sample show a much narrow but higher range from $7.36 \mathrm{pg}$ in $D$. rubiginosa to $7.88 \mathrm{pg}$ in $D$. horrida (HIREMATH and NAGASAMPIGE, 2004). In Lonchocarpus 51 diploid $(2 \mathrm{n}=22)$ taxa including 42 species show 4C DNA values ranging from $1.92 \mathrm{pg}$ in $L$. santarosanus to 2.86 in L. xuul depicting a 1.49-fold difference, which does not show any correlation with altitude (PALOMINO and Sousa, 2000).

Detailed studies have been made on 39 species of Sapindaceae belonging mainly to the tribe Paullinieae in which $1 \mathrm{C}$ values show a 9fold variation varying from $0.305 \mathrm{pg}$ in Lophostigma plumosum to $2.710 \mathrm{pg}$ in Cardiospermum heringeri (COULLERI et al., 2014). The genus Cardiospermum which has four basic numbers $(\mathrm{x}=7,9,10,11)$ depicts a 5.23 -fold difference varying from C. bahianum $(2 \mathrm{n}=4 \mathrm{x}=36$, $1 \mathrm{C}=0.519 \mathrm{pg})$ to $C$. heringeri $(2 \mathrm{n}=14,1 \mathrm{C}=2.715$ pg). Eight species of Paullinia which are all diploid $(2 \mathrm{n}=2 \mathrm{x}=24)$ show $1 \mathrm{C}$ values from $1.0 \mathrm{pg}$ in P. thallictrifolia to $2.061 \mathrm{pg}$ in $P$. elegans showing a 2.0-fold variation. In Serjania $(2 \mathrm{n}=2 \mathrm{x}=24) 1 \mathrm{C}$ values differ from $0.974 \mathrm{pg}(S$. marginata) to $2.68 \mathrm{pg}$ (S. caracasana) showing a 2.75-fold difference (CoulleRI et al., 2014). Similarly, new estimates for 47 species have been made in Fagaceae (CHEN et al., 2014) combining this with 31 estimates made earlier (BENNETT and LEITCH, 2010, KREMER et al., 2007) the overall difference in the family is 2.2fold between $1.2 \mathrm{pg} / 2 \mathrm{C}$ in Fagus sylvestris $(2 \mathrm{n}=24)$ and $2.61 / 2 \mathrm{C}$ in Lithocarpus calolepis $(2 \mathrm{n}=24)$. In the genus Quercus $(2 \mathrm{n}=24) 24$ species studied show 1.8-fold difference between $Q$. bicolor $(1.35 \mathrm{pg} / 2 \mathrm{C})$ and $Q$. austrocochinchinensis $(2.44 \mathrm{pg} / 2 \mathrm{C})$. The overall results show that two major tropical genera Lithocarpus 
$(2 \mathrm{n}=24)$ and Castanopsis $(2 \mathrm{n}=24)$ have significantly larger $2 \mathrm{C}$ values than the temperate genera and genome sizes of tropical evergreen species of Quercus (subgenus Cyclobalanopsis) are significantly larger than those of temperate subgenus Quercus. Furthermore, within temperate subgenus Quercus the evergreen species depict significantly larger genome sizes than the deciduous ones (CHEN et al., 2014).

Some examples show interesting patterns of variation taking place both at diploid and at polyploidy levels. This is exemplified by the genus Terminalia which shows a 3.5-fold difference between $T$. oliveri $(2 \mathrm{n}=2 \mathrm{x}=24,3.60 \mathrm{pg})$ and T. bellirica $(2 \mathrm{n}=4 \mathrm{x}=48,12.80 \mathrm{pg})$. Out of the six species studied T. oliveri, T. myriocarpa and T. arjuna are diploid $(2 \mathrm{n}=24), T$. chebula and $T$. bellirica are tetraploid $(2 \mathrm{n}=48)$ and $T$. muelleri is triploid $(2 \mathrm{n}=36)$. Difference of $1 \mathrm{Cx}$ DNA values is greatest (1.97-fold) between $T$. oliveri and T. arjuna. Two species groups are therefore well demarcated on the basis of their $1 \mathrm{Cx}$ values: T. oliveri $(2 \mathrm{x})$ and T. chebula $(4 \mathrm{x})$ (mean $1 \mathrm{Cx}=1.81 \mathrm{pg}$ ) and T. myriocarpa, $T$. arjuna, T. muelleri, and T. bellirica (mean $1 \mathrm{Cx}=3.34 \mathrm{pg}$ ). Within diploids and tetraploids there is 1.97 -fold and 1.76 -fold variation respectively in 1Cx values (OHRI, 1996). A study on 62 species of Magnolia having 2x, 4x and 6x ploidy levels shows a range of $2 \mathrm{C}$ values from $3.43 \mathrm{pg}$ in $M$. virginiana var. australis $(2 \mathrm{n}=2 \mathrm{x}=38)$ to $13.47 \mathrm{pg}$ in $M$. denudata $(2 \mathrm{n}=6 \mathrm{x}=114)$ a 3.9 fold variation. However, $1 \mathrm{Cx}$ values vary from $1.86 \mathrm{pg}$ in $M$. virginiana (2x) to $2.76 \mathrm{pg}$ in $M$. thailandica $(2 \mathrm{x})$. This shows that increase or decrease in genome size takes place both at diploid and polyploid levels (PARRIS et al., 2010). Eight taxa of Leucaena have been studied of which five diploid $(2 \mathrm{n}=56)$ taxa show $2 \mathrm{C}$ values from $1.35 \mathrm{pg}$ in L. esculenta subsp. esculenta to $1.81 \mathrm{pg}$ in $L$. diversifolia subsp. diversifolia showing 1.34-fold difference and three tetraploid taxa vary from $2.66 \mathrm{pg}$ in $L$. esculenta subsp. paniculata to $3.31 \mathrm{pg}$ in L. confertifolia subsp. adenotheloidea showing a 1.24-fold difference (PALOMINo et al., 1995). Similarly the Ternera ulmifolia complex $(\mathrm{x}=5)$ comprising of $2 \mathrm{x}, 4 \mathrm{x}$ and $8 \mathrm{x}$ species show a range of $2 \mathrm{C}$ values from $1.38 \mathrm{pg}$ in the diploid T. subulata $(2 \mathrm{n}=10)$ to $5.94 \mathrm{pg}$ in octoploid $T$. fernandezii $(2 \mathrm{n}=40)$. The $1 \mathrm{Cx}$ values reflect genome downsizing ranging from $0.44 \mathrm{pg}$ in T. cuneiformis $(8 \mathrm{x})$ to $0.98 \mathrm{pg}$ in T. grandidentata (4x) (LOPEZ et al., 2011). Eleven species of Berberis studied show a range of $2 \mathrm{C}$ values from $1.463 \mathrm{pg}$ in $B$. bidentata $(2 \mathrm{x})$ to $6.7 \mathrm{pg}$ in B. buxifolia $(4 \mathrm{x})$ showing a 4.6-fold difference. Three groups could be clearly indentified on the basis of $2 \mathrm{C}$ values and ploidy levels: first group comprises of diploid species $(2 \mathrm{n}=28)$ with $2 \mathrm{C}$ values ranging from $1.46 \mathrm{pg}$ to $1.85 \mathrm{pg}$ which grow in high elevation sites having greater rainfall with lower water availability, the second includes diploid species with $2 \mathrm{C}$ values from $2.9 \mathrm{pg}$ to $3.8 \mathrm{pg}$ and these are found at lower elevation with higher water availability and temperature and the third group consists of tetraploid $(2 \mathrm{n}=56)$ species with $2 \mathrm{C}$ values ranging from $5.8 \mathrm{pg}$ to $6.8 \mathrm{pg}$ and these show considerably wider distribution than the diploid species (BоTTINI et al., 2000).

Acacia is another example which shows wide variation at diploid and higher ploidy levels as depicted by 43 taxa studied (BUKHARI, 1997b). Six taxa from subgenus Heterophyllum differ in $2 \mathrm{C}$ values from $1.41 \mathrm{pg}$ in A. mearnsii $(2 \mathrm{n}=2 \mathrm{x}=26)$ to $3.3 \mathrm{pg}$ in $A$. holosericae $(2 \mathrm{n}=4 \mathrm{x}=52), 21$ taxa from subgenus Acacia vary from $1.056 \mathrm{pg}$ in A. tortilis $(2 \mathrm{n}=4 \mathrm{x}=52)$ to $2.2 \mathrm{pg}$ in $A$. nilotica var. adstringens $(2 \mathrm{n}=8 \mathrm{x}=104)$, while in subgenus Aculeiferum 16 taxa studied show a variation from $1.09 \mathrm{pg}$ in $A$. polycantha $(2 \mathrm{n}=4 \mathrm{x}=52)$ to $1.17 \mathrm{pg}$ in $A$. mellifera $(2 \mathrm{n}=2 \mathrm{x}=26)$. The mean $1 \mathrm{Cx}$ values of subgenera Heterophyllum, Acacia and Aculeiferum are $0.78 \mathrm{pg}, 0.29 \mathrm{pg}$ and $0.56 \mathrm{pg}$ respectively which shows that the subgenera differ greatly in the size of their chromosomes while abrupt differences in DNA content can also occur by polyploidy (BUKHARI, 1997). An interesting case of proportionate increase of holoploid genome size in an intraspecific polyploid series is shown in Acacia senegal with ploidy levels of $2 \mathrm{x}, 3 \mathrm{x}, 4 \mathrm{x}$ and $6 \mathrm{x}$ corresponding to $2 \mathrm{C}$ values of $1.47,2.12,2.89$ and $4.51 \mathrm{pg}$ respectively (ODEE et al., 2015). Although the species is predominantly diploid, the occurrence of diploid-polyploid complexes in northern range of Sub-Saharan Africa suggests the role of polyploidy in colonization and expansion in these regions (ODEE et al., 2015). Similarly, 31 species of genus Camellia belonging to section Thea show a 1.5 -fold variarion in $2 \mathrm{C}$ values ranging from $4.45 \mathrm{pg}$ in $C$. gymnogyna to $6.51 \mathrm{pg}$ in $C$. ptilophylla. The section Camellia is more complicated because of frequent interspecific hybridization and polyploidy. The ploidy level in 53 species studied show a range of $2 \mathrm{x}, 4 \mathrm{x}, 6 \mathrm{x}, 8 \mathrm{x}, 10 \mathrm{x}$, and $12 \mathrm{x}$. The $2 \mathrm{C}$ values varied 
8.9-fold from $2.86 \mathrm{pg}$ in C. delicata to $25.35 \mathrm{pg}$ in $C$. lanosituba (HUANG et al., 2013). In addition to this the 2C DNA amount also varies 2fold in diploid species which shows that DNA amount is varying both at diploid and polyploid levels (HUANG et al., 2013).

Some studies are available which allow the comparison of genome size between woody and herbaceous taxa within certain narrow taxonomic groups or even among congeneric species. The genus Cassia is a fine example which comprises arboreal, shrubby and herbaceous species. Ten species studied are all diploid with $2 \mathrm{n}=28$ except $C$. tora which has $2 \mathrm{n}=26$. The $2 \mathrm{C}$ DNA values in herbaceous species vary from $1.30 \mathrm{pg}$ (C. absus) to $1.36 \mathrm{pg}$ (C. occidentalis), shrubby species vary from $1.43 \mathrm{pg}$ (C. auriculata) to $1.47 \mathrm{pg}$ (C. biflora) while arboreal species studied show $1.39 \mathrm{pg}$ (C. fistula), $1.40 \mathrm{pg}$ (C. siamea) and $2.54 \mathrm{pg}$ (C. excelsa). Therefore, interestingly one of the arboreal species $C$. excelsa has 1.9-fold bigger genome size than the average value of the herbaceous species (Ohri et al. 1986). Similarly in Medicago the genome size is known for 8 species. The sole arboreal species $M$. arborea $(2 \mathrm{n}=4 \mathrm{x}=32)$ with $2 \mathrm{C}=3.60$ $\mathrm{pg}$ is 2.26-fold greater than the average $2 \mathrm{C}$ value $(2 \mathrm{C}=1.58 \mathrm{pg})$ of 5 diploid $(2 \mathrm{n}=2 \mathrm{x}=16)$ herbaceous species while rest of the two tetraploid $(2 \mathrm{n}=32)$ herbaceous species $M$. sativa $(2 \mathrm{C}=3.5 \mathrm{pg})$ and $M$. glutinosa $(2 \mathrm{C}=3.9 \mathrm{pg})$ have similar values as the arboreal species (BENNETT and LEITCH, 2010). In the family Asteraceae genome sizes have been reported to range from $0.8 \mathrm{pg}$ in Leontodon longirostris to $56.56 \mathrm{pg}$ in Coreopsis nuecensis (VALLES et al., 2013). Later a sample of 167 taxa of Asteraceae studied by GARCIA et al. (2013), showing a range from $1.12 \mathrm{pg}$ in Inula heleniodes to $29.38 \mathrm{pg}$ in Santolina chamaecyparissus, also included a woody species Dasyphyllum villosum which shows a genome size $(2 \mathrm{C}=8.44 \mathrm{pg})$ much higher than most of the herbaceous species in the family (GARCIA et al., 2013). Similarly 10 species of Cornus show variation in $1 \mathrm{Cx}$ from $1.07 \mathrm{pg}$ in C. canadensis $(2 \mathrm{n}=4 \mathrm{x}=44)$ to $5.08 \mathrm{pg}$ in $C$. eydeana $(2 \mathrm{n}=2 \mathrm{x}=18)$ showing a 4.7 -fold difference. Remarkably, the average $1 \mathrm{Cx}$ value $(2.60$ pg) of 9 arboreal species is 2.42-fold greater than C.canadensis which is a creeping, rhizomatous perennial herbaceous subshrub growing to $20 \mathrm{~cm}$ tall (SHEARER and RANNEY, 2013). These examples show that woody taxa within certain taxonomic groups in fact possess larger genome sizes than their closely related herbaceous taxa.

\section{Insular and secondary woodiness}

It is now known that many insular woody species have evolved, following adaptive change, from their continental herbaceous colonizer species. This is substantiated by recent molecular studies in which the insular woody species of some genera have been shown to be closely related to their herbaceous relatives on the mainland some of the examples are: Aeonium (BoHle, 1996), Echium (MES AND 'T HART, 1996), Viola (BALlaRd and SYTSEMA, 2000), Eryngium (CALVINO et al., 2010), Senecio (PELSER et al., 2010), Fitchia (HufFord et al., 2003). LENs et al. (2013) have listed a number of species belonging to the families Crassulaceae, Fabaceae, Euphorbiaceae, Brassicaceae, Resedaceae, Malvaceae, Amaranthaceae, Caryophyllaceae, Polygonaceae, Gentianaceae, Rubiaceae, Lamiaceae, Plantaginaceae, Convulvulaceae, Boraginaceae, Apiaceae, Asteraceae, Caprifoliaceae showing insular woodiness on the Canary Islands. The question which arises here, in the present context, is how do the genome sizes of these insular woody species compare with that of their herbaceous relatives or does the change to woody habit lead to some alterations in genome size.

The $2 \mathrm{C}$ values of 13 Echium $(2 \mathrm{n}=16)$ species from Canary Islands show a range from $0.64 \mathrm{pg}$ (E. bonnetii) to $1.01 \mathrm{pg}$ ( $E$. aculeatum and $E$. hierrense) (SUDA et al., 2005). Interestingly, the average genome size of 12 woody species $(2 \mathrm{C}=0.84-1.01 \mathrm{pg})$ is 1.5 -fold more than that of the only herbaceous species $E$. bonnetii $(2 \mathrm{C}=0.64 \mathrm{pg})$ (SuDA et al., 2005). Another interesting case is of secondarily woody sunflower (Moyers and RIESEBERG, 2013). The woody perennial winteri ecotype showed early development of vascular cambium and late flowering as compared to the typical Helianthus annuus. However, no difference in genome size was seen between the typical and mutant (woody) sunflower types (MOYERS and RIESEBERG, 2013).

\section{Conclusions}

The foregoing account shows that the genome size of hardwoods is not as constrained and limited in size as has been considered. Hardwoods have been shown to be genomically and kary- 
ologically as diverse as their herbaceous counterparts. The genome size can show dramatic changes at homoploid levels as well as by the development of polyploidy series, natural triploidy and by induced polyploidy. These changes have been shown to have effect on their adaptability and geographic distribution. Moreover, the genome size, in certain groups having both herbaceous and woody taxa, is not correlated with the habit as woody taxa may be showing bigger genome size than their related herbaceous taxa. This anomaly is further exemplified by the insular or secondarily woody species where the insular woody species in some genera have on an average bigger genome size than the herbaceous species and secondary woodiness does not lead to any changes in the genome size. It can be concluded that while hardwoods may not have developed massive genome sizes like conifers but their genome sizes may not be as small and constrained as has been generally considered as they show remarkable variation both at holoploid and at $1 \mathrm{Cx}$ levels.

\section{Acknowledgements}

The author is grateful to Maj. Gen K. K. OHRI (Retd.), Pro Vice-Chancellor, and Dr. Q. RAHMAN DEAN, Department of Research, Amity University, Uttar Pradesh, Lucknow Campus for encouragement and support.

\section{References}

AsamaA, K., A. Sober and M. Rahi (2001): Leaf anatomical characteristics associated with shoot hydraulic conductance and stomatal sensitivity to changes of leaf water status in temperate deciduous trees. Australian J Pl Physiology 28: 765-774.

Ballard, H. E. and K. J. Sytsma (2000): Evolution and biogeography of the woody Hawaiian violets (Viola, Violaceae): arctic origins, herbaceous ancestry and bird dispersal. Evolution 54: 1521-1532.

Beaulieu, J. M., I. J. Leitch, S. Patel, A. PendHARKAR and C. A. KNIGHT (2008): Genome size is a strong predictor of cell size and stomatal density in angiosperms New Phytologist 179: 975-986.

Beaulieu, J. M., S. A. SMith and I. J. Leitch (2010): On the tempo of genome size evolution in angiosperms. J. Bot. doi:10.1155/2010/989152.

Beck, S. L., R.W. Dunlop and A. Fossey (2003): Evaluation of induced polyploidy in Acacia mearnsii through stomatal counts and guard cell measurements. South African Journal of Botany 69: $563-567$.
BEDI, Y. S., S. S. BIR and B. S. GILL (1981): Cytopalynology of woody taxa of family Rubiaceae from north and central India. Proc. Indian Natl Sci Acad B47: 708-715.

Bennett, M. D. (1971): The duration of meiosis. Proc Roy Soc Lond Ser B 178: 259-275.

BennetT, M. D. (1972): Nuclear DNA content and minimum generation time in herbaceous plants. Proc Roy Soc Lond Ser B 181: 109-135.

BENNETT, M. D. (1987): Variation in genomic form in plants and its ecological implications. New Phytologist 106: 177-200.

Bennett, M. D.and I. J. Leitch (2010): Angiosperm DNA C-values Database (release 5.0, Dec. 2010). Available at http://www.kew.org/genomesizes/homepage.

Bennett, M. D., I. J. LeItCH and L. HANson (1998): DNA amounts in two samples of angiosperm weeds. Ann Bot 82: 121-134.

Benson, M. K. and D.W. Einspahr (1967): Early growth of diploid, triploid and triploid hybrid aspen. Forest Science 13: 150-155.

Besnard, G., C. Garcia-Verdugo, R. Rubio de Casas, U. A. Treier, N. Galland and P. Vargas (2008): polyploidy in the olive complex (Olea europaea): evidence from flow cytometry and nuclear microsatellite analyses. Ann Bot 101: 25-30.

Biswas, B. K. and A. K. Sharma (1984): Chromosome studies in the family Magnoliaceae. Cytologia 49: 193-200.

Blakesley, D., A. Allen, T. K. Pellny and A.V. RoBERTs (2002): Natural and induced polyploidy in Acacia dealbata Link. and Acacia mangium Willd. Ann Bot 90: 391-398.

Bohle, U. R., H. H. Hilger and W. F. MARTiN (1996): Island colonization and evolution of the insular woody habit in Echium L. (Boraginaceae). Proc. Natl. Acad Sci. USA 93: 11740-11745.

Bottini, M. C. J., E. J. Greizerstein, M. B. Aulicino and L. Poggio (2000): Relationships among genome size, environmental conditions and geographical distribution in naturalpopulations of NW Petgonian species of Berberis L. (Berberidaceae). Ann Bot 86: 565-573.

BukHARI, Y. M. (1997a): Cytoevolution of taxa in Acacia and Prosopis (Mimosaceae). Hereditas 126: 195-197.

BUKHARI, Y. M. (1997b): Nuclear DNA amounts in Acacia and Prosopis (Mimosaceae) and their evolutionary implications. Hereditas 126: 45-51.

BuRdA, R. I. and F. L. SHChepotiev (1973): Spontaneous polyploidy in seedlings of multi-seeded acorns of Quercus robur L. Cytology and Genetica 7: 140-143 (in Russian).

ButorinA, A. K. (1993): Cytogenetic study of diploid and spontaneous triploid oaks, Quercus robur L. Ann Sci For 50 Suppl 1: 114s-150s.

Calvino, C. I., S. G. Martinez and S. R. Downie (2010): Unraveling the taxonomic complexity of Eryngium L. (Apiaceae, Saniculoideae): phylogenetic analysis of 11 non-coding cpDNA loci corrobo- 
rates rapid radiations. Plant Divers Evol 128: 137-149.

Chen, G., W-B. Sun, C-Y. Han and A. Coombes (2007): Karyomorphology of the endangered Trigonobalanus doichangensis (A. Camus) Forman (Fagaceae) and its taxonomic and biogeographic implications. Bot J Linn Soc 154: 321-330.

Chen, G-Q., S-L. Guo and L-P. YIN (2010): Applying DNA C-values to evaluate invasiveness of angiosperms: validity and limitation. Biol Invasions 12: 1335-1348.

Chen, S-C., C. H. Cannon, C-S. Kua, J. J. LiU, D. W. Galbraith (2014): Genome size variation in the Fagaceae and its implications for trees. Tree Genetics and Genomes 10: 977-988.

ChoKChaichamnankit, P., K. AnamthaWAT-Jonsson and W. ChUlalaksananukul (2008): Chromosomal mapping of $18 \mathrm{~S}-25 \mathrm{~S}$ and $5 \mathrm{~S}$ ribosomal genes on 15 species of Fagaceae from northern Thailand. Silvae Genetica 57: 5-13.

Contreras, R. N. and J. M. Ruter (2011): Genome size estimates and chromosome numbers of Callicarpa L. (Lamiaceae). HortScience 46: 567-570.

Costa, I. R., M. C. Dornelas and E. R. Fornis-MarTINS (2008): Nuclear genome size variation in fleshy-fruited neotropical Myrtaceae. Pl Syst Evol 276: 209-217.

Costa, I. R. and E. R. Fornis-Martins (2006a): Chromosome studies in species of Eugenia, Myrciaria, and Plinia (Myrtaceae) from southeastern Brazil. Australian J. Botany 54: 409-415.

Costa, I. R. and E. R. Fornis-Martins (2006b): Chromosome studies in Brazilian species of Campomanesia Ruiz et Pavon and Psidium L. (Myrtaceae Juss.) Caryologia 59: 7-13.

Coulleri, J. P., M. Dematteis and M. S. Ferrucci (2012): A new insight into Serjania Mill. (Sapindaceae, Paullinieae) infrageneric classification: a cytogenetic approach. Pl Syst Evol 298: 1743-1753.

Coulleri, J. P., J. D. Urdampilleta and M. S. FERRUCCI (2014): Genome size evolution in Sapindaceae at subfamily level: a case study of independence in relation to karyological and palynological traits. Bot J Linn Soc 174: 589-600.

Cros, J. M., C. Combes, N. Chabrillange, C. DuperRAY, A. Monnot Des Angles and S. HAMon (1995): Nuclear DNA content in the subgenus Coffea (Rubiaceae): inter- and intra-specific variation in African species. Canadian J. Botany 73: 14-20.

D'Emerico, S., P. Bianco, P. Medagli and B. SchiRONE (1995): Karyotype analysis in Quercus species. Silvae Genetica 44: 66-70.

De, K. K., A. SAHA, R. TAMANG and B. Sharma (2010): Investigation on relative genome sizes and ploidy levels of Darjeeling-Himalayan Rhododendron species using flow cytometer. Indian J. Biotechnology 9: 64-68.

Dwivedi, N. K., N. Suryanarayana, A. K. Sikdar, B. N. Susheelamma and M. S. Jolly (1989): Cytomor- phological studies in triploid mulberry evolved by diploidization of female gamete cells. Cytologia 54: 13-19.

Dzialuk, A., I. Chybicki, M. Welc, E. Sliwinska and J. BuRCZYK (2007): Presence of triploids among oak species. Ann Bot 99: 959-964.

Ehrendorfer, F. (1987): Differentiation trends in tropical woody angiosperms. pp 227-237 in Differentiation patterns in higher plant, edited by K.M. Urbanska, Academic Press London.

Einspahr, D.W., M. K. Benson and J. R. PECKham (1963): Natural variation and heritability in triploid aspen. Silvae Genetica 12: 51-58.

El Ferchichi OuARDA, H., D. J. Walker, M. L. KHOUJA and E. CORREAL (2009): Diversity of Acacia tortilis (Forsk.) Hayne ssp. raddiana (Savi) Brenan (Mimosaceae) using phenotypic traits, chromosome counting and DNA content approaches. Genetic Resources Crop Evolution 56: 1001-1010.

Ferrucci, M. S. (2000): Cytotaxonomy of Sapindaceae with special reference to the tribe Paullinieae. Genetics and Molecular Biology 23: 941-946.

Francis, D., M. S. Davies and P. W. Barlow (2008): A strong nucleotypic effect on the cell cycle regardless of ploidy level Annals of Botany 101: 747-757.

FuRLOW, J. (1990): The genera of Betulaceae in the southeastern United States. J. Arnold Arboretum 71: $1-67$.

Garcia, S., M. A. Canela, T. Garnatje, E. D. McArthur, J. Pellicer, S. C. SANDerson and J. VALLES (2008): Evolutionary and ecological implications of genome size in the North American endemic sagebrushes and allies (Artemesia, Asteraceae) Biological J. Linnean Society 94: 631-649.

Garcia, S., O. Hidalgo, I. JaKovlJevic, S. SilJaKYakovleV, J. Vigo, T. GarnatJe and J. VAlles (2013): New data on genome size in 128 Asteraceae species and subspecies, with first assessments for 40 genera, 3 tribes and 2 subfamilies. Plant Biosystems 147: 1219-1227

GiLl, B. S., S. S. BIR and V. K. Singhal (1982): Cytogenetics of some timber species of Terminalia Linn. (Combretaceae). Proc. Indian Natl. Sci. Acad. B 48: 779-790.

Gill, B. S., V. K. Singhal, Y. S. Bedi and S. S. BiR (1990): Cytological evolution in the woody taxa of Pachmarhi Hills. J. Cytology \& Genetics 25: 308-320.

Grattapaglia, D. and H. D. Bradshaw (1994): Nuclear DNA content of commercially important Eucalyptus species and hybrids. Canadian J. Forest Res. 24: 1074-1078.

GregORY, T. R. (2001): Coincidence, coevolution, or causation? DNA content, cell size, and C-value enigma. Biological Review 76: 65-101.

Greilhuber, J., T. Borsch, K. Muller, A. Worberg, S. Porembski and W. BARThlott (2006): Smallest angiosperm genomes found in Lentibulariaceae, with chromosomes of bacterial size. Plant Biology 8: 770-777. 
Grime, J. P., A. J. Willis, R. Hunt and N. P. DunnetT (1985): Nuclear DNA contents, shoot phenology and species co-existance in a limestone grassland community. New Phytologist 100: 435-445.

Groover, A. T. (2005): What genes make a tree a tree? Trends Plant Sci. 10: 210-214.

Grotkopp, E., M. Rejmanek, J. M. SANDERson and T. L. Rost (2004): Evolution of genome size in pines (Pinus) and its life history correlates: supertree analysis. Evolution 58: 1705-1729.

Gruner, A., N. Hoverter, T. SMith and C. A. Knight (2010): Genome size is strong predictor of root meristem growth rate J. Botany doi:10.1155/2010/ 390414.

GU, X. F., A. F. YANG, H. Meng and J. R. Zhang (2005): In vitro induction of tetraploid plants from diploid Zizyphus jujube Mill. Cv. Zhanhua. Plant Cell Rep. 24: 671-676.

Hans, A. S. (1970): Polyploidy in Antidesma (Euphorbiaceae) Caryologia 23: 321-327.

Hao, G-Y., M. E. Lucero, S. C. SAnderson, E. H. ZACHARIAS and N. M. HolBrooK (2013): Polyploidy enhances the occupation of heterogeneous environments through hydraulic related trade-offs in Atriplex canescens (Chenopodiaceae). New Phytologist 197: 970-978.

Harbard, J. L., A. R. Griffin, S. Foster, C. Brooker, L. D. KHA and A. Koutoulis (2012): Production of colchicine-induced autotetraploids as a basis for sterility breeding in Acacia mangium Willd. Forestry doi:10.1093/forestry/cps041.

Hetherington, A. M. and F. I. WoOdwARD (2003): The role of stomata in sensing and driving environmental change. Nature 424: 901-908.

Hiremath, S. C. and M. H. NAGAsampige (2004): Genome size variation and evolution in some species of Dalbergia Linn.F. (Fabaceae). Caryologia 57: 367-372.

HuAnG, H., Y. Ton, Q-J. Zhang and L-Z. GAO (2013): Genome size variation among and within Camellia species by using flow cytometric analysis. Plos One 8: e64981.

Hufford, L., M. M. McMahon, A. M. Sherwood, J. ReEves and M. W. ChAse (2003): The major clades of Losaceae: phylogenetic analysis using the plastid matK and trnL-trnF region. Amer. J. Bot. 90: $1215-1228$.

Hunter, K. L., J. L. Betancourt, B. R. Riddle, T. R. Van Devender, K. L. Cole and W. G. Spaulding (2001): Ploidy race distributions since the last glacial maximum in the North American desert shrub, Larrea tridentate. Global Ecology and Biogeography 10: 521-533.

Hynniewta, M., S. K. MALIK and S. R. RAO (2011): Karyological studies in ten species of Citrus (Linnaeus, 1753) (Rutaceae) of Nort-East India. Comparative Cytogenenetics 5: 277-287.

KADOTA, M. and Y. NiImi (2002): In vitro induction of tetraploid plants from a diploid Japanese pear cultivar (Pyrus pyrifolia N. cv. Hosui). Plant Cell Rep. 21: 282-286,
Kноsноо, T. N. (1962): Cytogenetical evolution in gymnosperms-karyotype. Proceedings of the summer school Darjeeling. Government of India, Darjeeling, pp. 119-258.

Khoshoo, T. N. and N. Singh (1963): Cytology of North-West Indian trees I. Zizyphus jujube and $Z$. rotundifolia. Silvae Genetica 158-174.

Khosla, P. K. and B. T. Styles (1975): Karyological studies and chromosomal evolution in Meliaceae. Silvae Genetica 24: 73-83.

Knight, C. A. and J. M. Beaulieu (2008): Genome size scaling through phenotype space. Ann Bot 101: 759-766.

Kremer, A., M. Casasoli, T. Barreneche, C. Bodenes, P. Sisco, T. Kubisiak, M. Scalfi, S. Leonardi, E. Bakker, J. Buiteveld, J. Romero-Severson, K. Arumuganathan, J. Derory, C. Scotti-Saintagne, G. Roussel, M. E. Bertocchi, C. Lexer, I. Porth, F. Hebard, C. Clark, J. Carlison, C. Plomion, H. P. KoElewiJn and F. Villani (2007): Fagaceae trees, pp161-186 in Genome mapping and molecular breeding in plants, vol.7 Forest tree edited by C. Kole, Springer Verlag Berlin, Heidelberg.

Kubesova, M., L. Moracova, J. SudA, V. JarosiK and P. PYseK (2010): Naturalized plants have smaller genomes than their non-invading relatives: a flow cytometric analysis of the Czech alien flora. Preslia 82: 81-96.

Kumar, A. and S. R. RAO (2002): Cytological investigations in some important tree species of Rajasthan I. Karyomorphological studies in some species of Anogeissus (DC.) Guill., Perr. \& Rich. Silvae Genet. 51: 104.

LAM, H. K., J. L. HARBARD and A. Koutoulis (2014): Tetraploid induction of Acacia crassicarpa using colchicine and oryzalin. J Tropical Forest Sci 26: 347-354.

Lavergne, S., N. J. Muenke and J. Molofsky (2010): Genome size can trigger rapid phenotypic evolution in invasive plants. Ann Bot. 105: 109-116.

Lefort, F., G. C. Douglas and D. Thompson (2000): Microsatellite DNA profiling of phenotypically selected clones of Irish oak (Quercus spp.) and ash (Fraxinus excelsior L.) Silvae Genetica 49: 21-28.

Lefort, F., M. LAlly, D. Thompson and G. C. DouGLAS (1998): Morphological traits, microsatellite fingerprinting and genetic relatedness of a stand of elite oaks $(Q$. robur L.) at Tullynally, Ireland. Silvae Genetica 47: 257-262.

Leitch, I. J., M. W. Chase and M. D. BennetT (1998): Phylogenetic analysis of DNA C-values provides evidence for a small ancestral genome size in flowering plants. Ann Bot 82 (Supplement A) 85-94.

Lens, F., N. Davin, E. Smets and M. Del Arco (2013): Insular woodiness on the Canary Islands: A remarkable case of convergent evolution. Int $\mathrm{J}$ Plant Sci 174: 992-1013.

Lin, H., M. JiAN, L. Y. LIANG, W. J. PEI, X. Z. LiU and H.Y. ZHANG (2010): Production of polyploids from cultured shoot tips of Eucalyptus globulus Labill by treatment with colchicine. African J Biotechnology 9: 2252-2255. 
LIU, G., Z. LI and M. BAO (2007): Colchicine-induced chromosome doubling in Platanus acerifolia and its effect on plant morphology. Euphytica 157: $145-154$.

Lomax, B. H., F. I. Woodward, I. J. Leitch, C. A. KNIGHT and J. A. LAKE (2009): Genome size as a predictor of guard cell length in Arabidopsis thaliana is independent of environmental conditions New Phytologist 181: 311-314.

Lopez, A., A. F. PANseri, L. Poggio and A. Fernandez (2011): Nuclear DNA content in the polyploidy complex Turnera ulmifolia (Turnera L., Passifloraceae). Pl Syst Evol 296: 225-230.

Mathur, N., K. G. RAMAWAT and G. NANDWANI (1995): Rapid in vitro multiplication of jujube through mature stem explants. Plant Cell Tissue Organ Culture 43: 75-77.

MeHRA, P. N. (1972): Cytogenetical evolution of hardwoods. Nucleus 15: 64-83.

Mehra, P. N., A. S. Hans and T. S. Sareen (1972): Cytomorphology of Himalayan Fagaceae. Silvae Genet 21: 102-109.

MenrA, P. N. (1976): Cytology of Himalayan hardwoods. Sree Saraswaty Press, Calcutta.

Mehra, P. N., T. S. Sareen and P. K. Khosla (1972): Cytological studies on Himalayan Meliaceae. J Arnold Arboretum 53: 558-568.

Mehra, P. N. and K. S. BAwA (1969): Chromosome evolution in tropical hardwoods. Evolution 23: 241-252.

MEs, T. H. M. and H.'T HART (1996): The evolution of growth forms in the Macronesian genus Aeonium (Crassulaceae) inferred from chloroplast DNA RFLPs and morphology. Mol Ecol 5: 351-363.

MishrA, M. K. (1997): Stomatal characteristics at different ploidy levels in Coffea L. Ann Bot 80: 689-692.

Mock, K. E., C. M. Callahan, M. Nurul IslamFARIdi, J. D. Shaw, H. S. Rai, S. C. SANDERson, C. A. Rowe, R. J. Ryel, M. D. MAdRItCh, R. S. GardNER and P. G. WOLF (2012): Widespread triploidy in western north American aspen (Populus tremuloides). Plos One 7: e48406.

MoRAWETZ, W. (1986): Remarks on karyological differentiation patterns in tropical woody plants. Pl Syst Evol 152: 49-100.

Moyers, B. T. and L. H. RIEseberG (2013): Divergence in gene expression is uncoupled from divergence in coding sequence in a secondarily woody sunflower. Int. J. Plant Sci 174: 1079-1089.

Mu, H-Z, Z-J. LIU, L. LIN, H-Y. LI, J. JiANG and G-F. LIU (2012): Transcriptomic analysis of phenotypic changes in Birch (Betula platyphylla) autotetraploids. Int. $J$ Mol Sci 13: 13012-13029.

MurRAY, B. G. (1998): Nuclear DNA amounts in gymnosperms. Ann. Bot. 82A: 3-15.

Nassar, N. M. A., D. Garciano-Rebeiro, S. D. FerNANDES and P. C. ARAUJO (2008): Anatomical alterations due to polyploidy in cassava (Manihot esculenta Crantz). Genet Mo Res 7: 276-283.
NAujoks, G., H. Hertel and D. EwAld (1995): Characterization and propagation of an adult triploid pedunculate oak (Quercus robur L.) Silvae Genetica 44: 282-286.

Nesom, G. L. (2010): Fraxinus biltmoreana and Fraxinus smallii (Oleaceae) forest trees of the eastern United States. Phytoneuron 51: 1-30.

Noirot, M., V. Poncet, P. Barre, P. Hamon, S. HAMON and A. DE KochKo (2003): Genome size variation in diploid African Coffea species. Ann Bot 92: 709-714.

Oballa, P. O. and P. A. S. Olingotie (1993): Chromosome numbers in two African Acacia species. Kew Bulletin 49: 107-113.

Odee, D.W., J. Wilson, S. Omondi, A. Perry and S. CAVERS (2015): Rangewide ploidy variation and evolution in Acacia senegal: a north-south divide? AoB Plants 7:plv011;doi:10.1093/aobpla/plv011.

OHRI, D. (1996): Genome size and polyploidy variation in the tropical hardwood genus Terminalia (Combretaceae). Pl Syst Evol 200: 225-232.

OHRI, D. (2002): Genome size variation in some tropical hardwoods. Biologia Plantarum. 45: 455-457.

OHRI, D. (2005): Climate and growth form: the consequences for genome size Plant Biology 7: 449-458.

OHRI, D. and M. R. AHuJA (1990): Giemsa C-banded karyotype in Quercus L. (oak). Silvae Genet 39: 216-219.

OHRI, D. and M. R. AHuJA (1991): Giemsa C-banding in Fagus sylvatica L., Betula pendula Roth and Populus tremula L. Silvae Genet 40: 72-75.

OHRI, D. and T. N. KHoshoo (1987): Nuclear DNA contents in the genus Ficus (Moraceae). Pl Syst Evol 156: 1-4.

OHRI, D. and T. N. Khoshoo (1986): Genome size in gymnosperms. Pl Syst Evol 153: 119-132.

OHRI, D. and A. KUMAR (1986): Nuclear DNA amounts in some tropical hardwoods. Caryologia 39: 303-307.

OHRI, D. and K. Pistrick (2001): Phenology and genome size variation in Allium L. - a tight correlation? Plant Biology 3: 654-660.

OHRI, D. and S. N. ZADOO (1986): Cytogenetics of cultivated bougainvilleas IX. Precocious centromere division and origin of polyploidy taxa. Plant Breed 97: 227-231.

Ohri, D., A. Bhargava and A. Chatterjee (2004): Nuclear DNA amounts in 112 species of tropical hardwoods-new estimates. Plant Biol 6: 555-561.

OHRI, D., A. KumAR and M. PAL (1986): Correlations between 2C DNA values and habit in Cassia (Leguminosae-Caesalpinioideae). Pl Syst Evol 153: $223-227$.

OudjeHIH, B. and A. BentouAti (2006): Chromosome numbers of the 59 species of Eucalyptus L'Herit. (Myrtaceae). Caryologia 59: 207-212.

Palomino, G., G. Romo and S. Zarate (1995): Chromosome numbers and DNA content in some taxa of Leucena (Fabaceae Mimosoideae). Cytologia 60: 31-37. 
Palomino, G. and M. Sousa (2000): Variation of nuclear DNA content in the biflorus species of Lonchocarpus (Leguminosae). Ann Bot 85: 69-76.

PARRIS, J. K., H. T. KNAP and W. C. BAIRD (2010): Ploidy levels, relative genome sizes, and base pair composition in Magnolia. J. Amer. Hort Soc 135: 533-547.

Pellicer, J., M. F. FAY and I. J. Leitch (2010): The largest eukaryotic genome of them all? Bot J Linn Soc 164: 10-15.

Pelser, P. B., E. J. Tepe, A. H. Kennedy and L. E. Watson (2010): The fate of Robinsonia (Asteraceae): sunk in Senecio, but still monophyletic? Phytotaxa 5: 31-46.

Petit, R. J. and A. Hempe (2006): Some evolutionary consequences of being a tree. Annual Rev Ecol Evol Syst 37: 187-214.

Razafinarivo, N. J., J. J. Rakotomalala, S. C. Brown, M. Bourge, S. Hamon, A. DE KochKo, V. Poncet, C. Dubreuil-Tranchant, E. Couturon, R. GuYot and P. HAMON (2012): Geographical gradients in the genome size variation of wild coffee trees (Coffea) native to Africa and Indian Ocean Islands. Tree Genetics and Genomes 8: 1345-1358.

Ribeiro, T., J. Loureiro, C. Santos and L. MoraisCECILIO (2011): Evolution of rDNA patterns in the Fagaceae. Tree Genetics and Genomes 7: 113-1122.

Rose, J. B., J. KubBa and K. R. Toвutт (2000): Induction of tetraploidy in Buddleia globosa. Plant Cell Tiss Organ Cult 63: 121-125.

SARKILAHTI, E. and T. VALANNE (1990): Induced polyploidy in Betula. Silva Fennica 24: 227-234.

Shao, J. Z., C. I. Chen and X. X. Deng (2003): In vitro induction of tetraploid in pomegranate (Punica granatum). Plant Cell Tissue and Organ Culture 75: 241-246.

Shearer, K. and T. G. RANney (2013): Ploidy levels and relative genome sizes of species, hybrids, and cultivars of dogwood (Cornus spp.) HortScience 48: 825-830.

Simova, I. and T. Herben (2011): Geometrical constraints in the scaling relationships between genome size, cell size and cell cycle length in herbaceous plants. Proc $R$ Soc B doi:10.1098/rspb.2011.1284.

Singhal, V. K., B. S. GILL and S. S. BIR (1985): Cytology of woody species. Proc Indian Acad Sci (Plant Sci) 94: 607-617.

Stebbins, G. L. (1950): Variation and Evolution in Plants. Columbia University Press, New York.

Styles, B. T. and C. G. Vosa (1971): Chromosome numbers in the Meliaceae. Taxon 20: 485-499,

SudA, J., T. KYNCL and V. JARolimova (2003): Genome size variation in Macronesian angiosperms: forty percent of the Canarian endemic flora completed. Pl Syst Evol 252: 215-238.
TANG, Z-Q., D-L. Chen, Y-C. HE and D-T. CAI (2010): In vitro induction and identification of tetraploid plants of Paulownia tomentosa. Plant Cell Tiss Organ Cult 102: 213-220.

Urdampilleta, J. D., M. S. Ferrucci, J. M. D. TorezAN and A. L. L. VANZELA (2006): Karyotype relationships among four South American species of Urvillea (Sapindaceae: Paullinieae). Pl Syst Evol 258: 85-95.

VAINOLA, A. (2000): Polyploidization and early screening of Rhododendron hybrids. Euphytica 112: 239-244.

Valles, J., M. A. Canela, S. Garcia, O. Hidalgo, J. Pellicer, I. SANCHEZ-Jeminez, S. SilJAKYakovlev, D. Vitales and T. Garnatje (2013): genome size variation and evolution in the family Asteraceae. Caryologia 66: 221-235.

VERMA, R. C., A. SARKAR and S. SARKAR (1986): Induced amphiploids in mulberry. Curr Sci 55: 1203-1205.

Walker, D. J., I. Monino, E. Gonzalez, N. FraYssinet and E. CORREAL (2005): Determination of ploidy and nuclear DNA content in populations of Atriplex halimus (Chenopodiaceae). Bot J Linn Soc 147: 441-448.

WANG, H-C., A-P. Meng, J-Q. Li and Y-K. Sima (2005): A karyotypic study on Manglietia (Magnoliaceae) from China. Caryologia 58: 189-199.

Wang, J., L. ShI, S. Song, J. TIAn and X. Kang (2013): Tetraploid production through zygotic chromosome doubling in Populus. Silva Fennica 47no.2 article id 932.

WANG, Z., M. WANG, L. LiU and F. Meng (2013): Physiological and proteomic responses of diploid and tetraploid black locust (Robinia pseudoacacia L.) subjected to salt stress. Int J Mol Sci 14: 2029920325, doi:10.3390/ijms141020299.

Wei, L., H. Dong-Nan, L. Hui and C. XiaO-Yang (2007): Polyploid induction of Lespedeza formosa by colchicines treatment For Stud China 9: 283-286.

Whittemore, A. and R. T. Olsen (2011): Ulmus americana (Ulmaceae) is a polyploidy complex. Amer J Bot 98: 754-760.

WoODWARD, F. I. (1998): Do plants really need stomata? J Experimental Bot 49: 471-480.

Zadoo, S. N., R. P. Roy and T. N. Khoshoo (1975): Cytogenetics of cultivated bougainvilleas V. Tetraploidy and restoration of fertility in sterile cultivars. Euphytica 24: 517-524.

Zhang, Q. Y., F. X. Luo, L. LiU and F. C. Guo (2010): In vitro induction of tetraploids in crape myrtle (Lagerstroemia indica L.). Plant Cell Tiss Organ Cult 101: 41-47.

Zoldos, V., D. Papes, M. Cerbah, O. Panaud, V. Besendorfer and S. SIlJAK-YAKOVlev (1999): Molecular cytogenetic studies of ribosomal genes and heterochromatin reveal conserved genome organization among 11 Quercus species. Theor Appl Genet 99: 969-977. 